\title{
LAMOST 望远镜
}

\author{
施建荣 \\ 中国科学院国家天文台, 北京 100012 \\ E-mail: sjr@bao.ac.cn \\ 2015-08-28 收稿, 2015-10-14 修回, 2015-10-15 接受, 2015-12-10 网络版发表 \\ 科技部重大科学研究计划(2014CB845700)资助
}

摘要 LAMOST望远镜是我国自主创新设计和研制的世界上最大口径的大视场望远镜，也是目前世界上光谱 获取率最高的望远镜. 它的研制成功改变了我国在大规模光谱观测和大型天文基础观测数据方面空白的面貌. LAMOST作为国家设备向全国天文界开放，并积极开展国际合作．LAMOST致力于银河系内恒星的巡天，为开展 银河系结构和演化前沿研究, 精确描绘银河系, 特别是银盘的星族、恒星运动和金属丰度分布, 揭示银河系恒星形 成和化学增丰历史, 精确绘制银河系物质组成等方面研究提供了大量可靠的光谱观测数据.

关键词 LAMOST 望远镜, 光谱巡天, 银河系形成和演化

大天区面积多目标光纤光谱天文望远镜 (英文简 称LAMOST, 中文名为郭守敬望远镜) 是一架新类型 大口径的大视场望远镜, 即 “王-苏反射施密特望远 镜”, ${ }^{[1,2]}$ (图 1). 它由反射施密特改正板 MA(由 24 块对 角线长 $1.1 \mathrm{~m}$ 、厚度 $25 \mathrm{~mm}$ 的六角形平面子镜组成的大 小为 $5.72 \mathrm{~m} \times 4.40 \mathrm{~m}$ 的平面镜)、主镜 $\mathrm{MB}$ (由 37 块对角 线长 $1.1 \mathrm{~m}$ 、厚度 $75 \mathrm{~mm}$ 的六角形球面子镜组成的大小 为 $6.67 \mathrm{~m} \times 6.05 \mathrm{~m}$ 的球面镜)和焦面构成. 球面主镜及 焦面固定在地基上, 反射施密特改正板作为定天镜 跟踪天体的运动, 望远镜在天体经过中天前后 $2 \mathrm{~h}$ 内 可以观测. 天体的光经MA反射到 $M B$, 再经MB反射 后成像在焦面上. 焦面上放置的光纤将天体的光分 别传输到 16 台光谱仪的狭缝上, 然后通过光谱仪后 的CCD探测器同时获得这些天体的光谱.

LAMOST应用了薄镜面主动光学加拼接镜面主 动光学技术, 在世界上首次在一块大镜面上同时应 用薄变形镜面和拼接镜面主动光学技术(控制镜面面 形精度达发丝的数千分之一); 实现了六角形的主动 可变形镜, 并在一个光学系统中同时采用两块大口
径拼接镜面. 由于它的大视场, 在 $5^{\circ}$ 视场、直径为 $1.75 \mathrm{~m}$ 的焦面上可以放置 4000 根光纤(同类设备当时 为 640 根), 并采用并行可控的光纤定位技术解决了 同时精确定位 4000个观测目标的难题. 它是一架具 有国际前沿水平的、高精度复杂的光学和机电一体化 系统, 在整个系统中还包括近 1 万个各种电机和促动 器定位器, 1000多个各种传感器, 以及控制各部分硬 件的大量软件系统、观测控制系统和数据处理系统.

LAMOST安放在中国科学院国家天文台兴隆观 测站, 该站地处燕山主峰南麓, 位于河北省兴隆县连 营寨 (东经 7 小时 50 分, 北纬 $40^{\circ} 23^{\prime}$ ), 海拔 $960 \mathrm{~m}$. LAMOST工程分为 8 个子系统: 光学系统、主动光学 和镜面支撑、机架和跟踪装置、望远镜控制、焦面仪 器、圆顶、观测控制和数据处理、输人星表和巡天战 略. 主要由国家天文台南京天文光学技术研究所、国 家天文台总部、中国科技大学和上海天文台承担完成.

LAMOST由我国自主创新设计和研制. 20世纪90 年代初, 面临世界天文学的迅速发展, 我国著名天文 学家王绶琯院士和苏定强院士瞄准国际天文研究中 


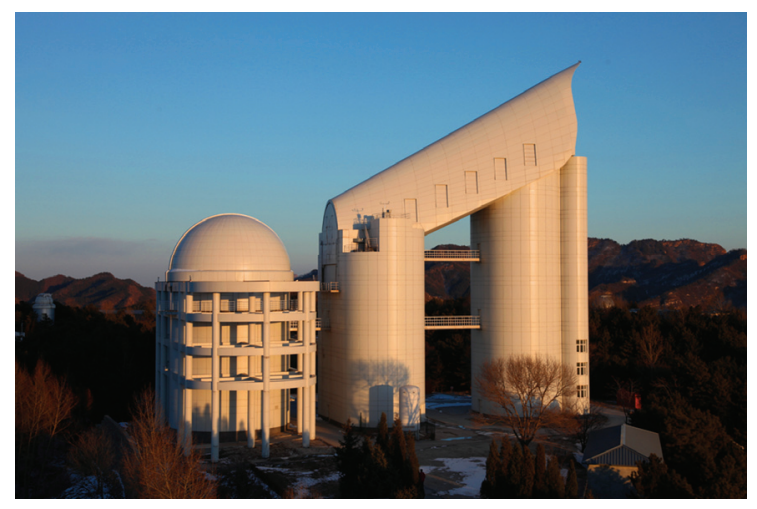

图 1 (网络版彩色) 夕阳中的LAMOST(由国家天文台陈颖为同志提供) Figure 1 (Color online) The LAMOST telescope at sunset (photograph by CHEN YinWei)

“大规模天文光谱观测严重缺乏”这一突破点, 提出 了一种“大口径与大视场兼备的天文望远镜”新概念, 并对望远镜整体设计有了创新的构想. 后来崔向群 院士、褚耀泉教授、王亚男研究员参与, 对望远镜整 体设计进行了细化、论证工作. 该项目由王绶琯和苏 定强院士为首的研究集体建议, 得到了天文界广泛 的支持, 由中国科学院提出, 经过反复论证, 于 1996 年列为国家重大科学工程项目, 1997年4月得到国家 计委关于项目建议书的批复, 1997年8月29日得到国 家计委关于项目可行性研究报告的批复. 2001年9月 正式开工建设, 经项目组全体人员艰苦拼搏、努力攻 关, 克服了重重困难, 于2008年 8 月底按期完成了全 部硬件安装, 并开始进行测试观测. 2009年6月4日通 过国家验收. 新型大视场兼大口径LAMOST光学天 文望远镜是我国具有国际竞争力的首台天文大科学 装置, 能同时获取最高4000个分布在 20 平方度视场 里天体的全光学波段(370 900 nm) 低色散(R 1800)光 谱. 从 2011 年9月开始了一年的先导巡天, 以了解望 远镜的性能和运行情况. 于2012年9月开始, 启动了 5 年的正式巡天.

\section{1 科学目标}

人类研究宇宙, 就像蚂蚁研究人类一样困难, 不 能一直盯着某个星系去看它如何演化, 必须采取“人 口普查” 的方式, 观测尽可能多的天体样本, 才能获 取更为准确、完整的科学认知. 作为一门观测驱动、 发现导向的实测科学, 天体的光谱在天体物理学研 究中发挥着非常关键的作用. 光谱是识别天体身份 的“基因”，它们包含了极其丰富的物理信息：恒星的
化学组成、温度、压力、视线方向的运动速度; 星系 的距离、构成、分布和运动等. 通过对光谱的分析研 究, 可以了解恒星、银河系乃至宇宙的形成、结构和 演化规律. 大量天体光学光谱的获取是涉及天文和 天体物理学诸多前沿问题的大视场、大样本天文学研 究的关键. 对世界的认知依赖于大规模天体样本的 获取和证认，但目前由“成像巡天”记录下的数以百 亿计的天体中, 只有很小的一部分(约万分之一)有过 光谱观测. LAMOST的建成为我国开展银河系大规模 光谱巡天, 研究银河系的结构、形成和演化并在世界 上占有一席之地提供了一个极为难得的、重要的历史 机遇 ${ }^{[3 \sim 5]}$.

LAMOST最初设定的“巡天计划”包括银河系结 构、星系红移巡天和多波段天体证认等领域, 开展银 河系内、外研究: 前者包括银河系形成、结构和演化, 搜找宇宙诞生后的第一代恒星等; 后者包括整个宇 宙的大尺度结构, 暗物质、暗能量的性质研究等. 根 据LAMOST望远镜当前的性能以及兴隆站的观测条 件, 目前巡天主要集中在银河系内恒星方面.

作为一个典型的盘星系, 银河系是唯一可以将 其星族组成解析为单体, 并对其在包括三维空间、三 维速度以及化学元素丰度的多维相空间里进行细致 研究的旋浴星系. 大量观测证据表明, 银河系仍处于 集成过程中, 还在不断吸积、吞并外来(矮)星系和星 团, 存在大量并合、吸积过程中因潮汐相互作用而形 成的星流等子结构. 由于我们身处银河系中, 其数千 亿颗恒星散布在全天 $4 \pi$ 立体角里. 因此要全面解析 和揭示银河系的三维空间结构、运动、物质(包括重 子和暗物质)分布、星族和星际介质的化学和动力学 性质，及其随时间的演化，必须开展覆盖全天的大规 模光谱巡天. 从而获取它们的空间位置、运动速度、 基本恒星参数(有效温度、表面重力、金属丰度)以及 距离和年龄等数据. 高精度的成像观测可以提供天 体在天球面上的二维坐标、亮度等信息, 获取高精度 的天体距离和在天球面上的切向速度则需要多历元 高精度成像观测. 而光谱观测则是获取恒星视向速 度及基本恒星参数的最有效和可靠的手段.

LAMOST银河系光谱巡天计划包括: (1) 银晕天 区, 银纬 $|b| \geqslant 20^{\circ} ;(2)$ 反银心天区, $|b| \leqslant 30^{\circ}$, 银经 $150^{\circ} \leqslant l \leqslant 210^{\circ} ;(3)$ 反银心天区外低银纬区域, 主要观 测目标为疏散星团. 可望在 5 年的时间里获得探测深 度达到 $r=17.8$ 等(少量天区达到 18.5 等)约 600 万条信 
噪比大于 10 的恒星光谱. 样本将包含分布在薄盘、厚 盘、晕及其过渡区域内的各类恒星, 实现在天区覆 盖、巡天体积、采样密度及统计完备性方面的重大突 破. 这些巡天光谱数据将为系统研究银河系特别是 银盘提供极好的、具有传承价值的样本.

利用LAMOST巡天光谱数据, 结合国内外其他光 学(如SDSS, IPHAS, UVEX)、红外(2MASS, WISE)、 紫外(Galex)巡天计划获取的测光数据, 可以得到大 样本银河系内恒星的大气参数 (有效温度、表面重力和 金属丰度), 以及 $\alpha$ 元素 $(\mathrm{Mg}, \mathrm{Ca})$ 与铁的丰度比 $[\alpha / \mathrm{Fe}]$ 和视向速度等, 从而为研究银河系星族、星际介质的 分布及其化学、动力学性质提供海量的观测数据. 不 仅如此, 将LAMOST巡天光谱数据与 Gaia将获取的 数以亿计银河系恒星的高精度的视差和自行信息相 结合, 将给出恒星的三维空间位置和速度、轨道参数 及恒星年龄等, 从而得到银河系中各有关星族恒星 的六维运动学参数(位置和空间速度) 以及在化学丰 度空间的分布等极其宝贵的信息. 利用这些信息可 以开展银河系结构和演化前沿研究, 精确描绘银河 系, 特别是银盘的星族和星际介质的三维空间结构、 恒星运动和金属丰度分布, 揭示银河系恒星形成和 化学增丰历史, 澄清银晕的并合、吸积历史, 精确绘 制银河系物质(包括暗物质)分布, 发现一批有重要研 究价值的特殊天体, 在银河系及一般盘星系的形成 和演化研究前沿领域取得有重要国际影响和显示度 的重大成果.

本巡天将首次在国际上取得覆盖银河系薄盘、厚 盘及银晕一个相当大体积、包含数百万颗恒星高信噪 比光谱及高精度视向速度、大气参数测量的统计无偏 的高质量样本, 实现在天区覆盖、巡天体积和采样密 度方面的重大突破.

LAMOST大视场和多光纤优势也非常适合对大 量特殊多波段天体开展高效光谱证认、构建多波段天 体的完备大样本, 为研究其特殊物理性质提供重要 信息. 多波段天体证认将充分利用国际上大型观测 设备数据, 非常有利于提升LAMOST光谱巡天的国 际影响力与科学产出. 获得的多波段天体样本将在 国际上得到广泛应用, 使我国在多波段天体物理研 究上迅速达到国际先进水平.

\section{2 国内外同类装置的现状}

近20多年来, 一些大型巡天项目相继开展. 这些
项目的开展深化了我们对银河系的认识. 其中在国 际上产生了重要影响的代表性巡天计划有 $\operatorname{SDSS}^{[6]}$ 等. 历经 10 年观测, SDSS I期和II期完成了全天约 $1 / 4$ 天区 (主要是高银纬区域)近 12000 平方度、整体测光精度 达到 $1 \%$ 1.5\%、极限星等约22等、覆盖全光学波段 的 CCD五色测光资料, 同时还取得了近 100 万个星 系、 12 万颗类星体、 50 万颗恒星的低色散 $(R \sim 1800)$ 光学光谱 ${ }^{[7]}$. SDSS提供的史无前例的海量高精度测 光数据使得我们对银晕的认识有了质的提高, 获得 了一系列重要结果, 如发现了大量银晕中的矮星系 以及银河系吸积、并合矮星系、星团残留下的大批星 流等子结构, 为星系自下而上逐级集成的形成和演化 模式提供了有力的证据. 然而, SDSS 是以高银纬天区 为主要观测区域, 河外星系、类星体为主要观测对象 的巡天计划, 因此, 对银河系中恒星的采样不多.

在银河系的巡天方面, 早期有日内瓦-哥本哈根太 阳邻近巡天 ${ }^{[8]} 、 \mathrm{RAVE}^{[9]} 、 \mathrm{SDSS} / \mathrm{SEGUE}^{[7]}$ 和APOGEE ${ }^{[10]}$. 目前在进行中的有 GALAH(HERMES) ${ }^{[11]}$, APOGEE II 和 $\mathrm{Gaia}^{[12]}$ 等项目. 计划 中的还有 $4 \mathrm{MOST}^{[13]}$ 和 WEAVE ${ }^{[14]}$ 等巡天项目.

日内瓦-哥本哈根太阳邻近巡天的目标仅限于太阳 附近 $200 \mathrm{pc}$ 以内, 获得了 $\mathrm{V}$ 星等亮于 8.3 的 16682 颗 $\mathrm{F}$ 和 $\mathrm{G}$ 矮星的金属丰度、年龄、运动速度和轨道参数等, 并利 用测光色指数估算了金属丰度. 本巡天项目通过光谱 观测取得了样本星的视向速度信息, 但丰度的测量基 于光谱定标的测光数据, 测量精度对光谱型依赖较大.

SDSS的银河系研究扩展项目SEGUE, 只是对十 几条互不相连的穿越银盘的窄带做了测光观测. 受 有限观测时间和光纤数目 (640根) 的限制, 虽然 SEGUE和SEGUE-II 获得了 400 个天区内近 24 万颗恒 星的光谱数据 ${ }^{[7]}$, 但这些恒星分布在一个个分离的铅 笔束里, 类型多达十多种, 遴选判据复杂, 有很强的 选择效应, 因此, 很难开展有意义的统计分析工作.

RAVE巡天的目标是获得南天百万量级恒星的 中分辨率光谱, 确定了这些恒星的视向速度和元素 丰度以研究银河系的结构和化学动力学演化. RAVE 观测深度相对较浅 $(9<I<12)$, 且天区分布在 $|b| \geqslant 25^{\circ}$ 高 银纬区域，从2003 2013年，此项目共获取了574630 光谱, 其中包括483330个科学目标.

APOGEE 是 SDSS III 期子项目, 在 6年 (2008 2014年)的巡天过程中获取了 163000 个APOGEE目标 的高分辨率、高信噪比 $\mathrm{H}$ 波段光谱, 其中有 146000 个 
科学目标, 主要是亮于 $H=12.5$ 等晚型巨星的高分辨 近红外光谱, 主要的科学目标是研究银河系, 尤其是 内区的动力学结构和化学增丰历史. 目前正在进行 的有关银河系的巡天项目有 GALAH ${ }^{[15]}$, 将对 100 万 $\mathrm{V}$ 星等亮于14的恒星开展高分辨光学波段光谱观测, 获取详细的恒星元素丰度信息, 研究银河系恒星形 成和化学增丰历史. APOGEE II是APOGEE项目的继 续, 计划通过6年(2014 2020年)的巡天获取 50万颗亮 星, 特别是核球恒星的高分辨率红外光谱.

2013年12月 19日升空的欧空局新一代天体测量 卫星 $\mathrm{Gaia}^{[12]}$, 具有银河系整个恒星星族普查意义. Gaia将对全天进行多历元的测光和低分辨光谱观测. Gaia位置测量精度高达 10 微角秒. 除了给出前所未 有的 10 亿颗恒星的三角视差和自行之外, 还将得到 约 1 亿深至 15 等恒星的视向速度和几百万深至 12 等恒 星的大气参数.

LAMOST 的光谱获取率是 SDSS I 期、II期 (2000 2008年; 640根光纤)的6.25倍, III期(2008 2014 年, 1000 根光纤)的4倍. 主要针对银河系, 尤其是针 对其标志性结构银盘的天区覆盖连续、统计上完备的 大规模光谱巡天. 到2015年6月, 在先导巡天及3年正 式巡天过程中, 已经获取了 520 多万条光谱, 其中 450 多万条光谱的信噪比大于 10 , 并提供了一个 300 多万 条恒星光谱的恒星参数星表. 遥遥领先于目前世界 上所有已知巡天项目的恒星光谱 ${ }^{[16]}$.

在Gaia数据大约 2020 年释放之前, LAMOST银河 系巡天将是国际上最具竞争力的大规模银河系光谱 巡天计划. 即使在Gaia升空后, LAMOST极限星等 $r=17.8$ (少量天区可达 18.5)仍比GAIA光谱观测能力 深2 3个星等.

LAMOST已成为我国最大的光学望远镜、世界上 最大口径的大视场望远镜, 也是目前世界上光谱获 取率最高的望远镜. 它的研制成功使我国的大规模
光谱观测处于世界领先地位. 至今已有数十篇基于 LAMOST巡天数据的研究论文在The Astrophysical Journal(APJ)和Monthly Notices of the Royal Astronomical Society(MNRAS)等国际主流学术刊物发表. 2015年8月刊发在Research in Astronomy and Astrophysics(RAA)的“LAMOST巡天及早期成果”专刊又 发表了 22 篇基于LAMOST巡天数据的研究论文, 研 究成果涉及LAMOST巡天数据和分析、巡天样本构 建、具有特殊性质和研究价值天体的新发现以及银盘 的化学、动力学性质大样本研究 ${ }^{[17]}$. LAMOST作为国 家设备向全国天文界开放，并积极开展国际合作．它 将使人类观测天体光谱的数目提高一个数量级 (至千 万量级), 使我国在该领域处于国际领先地位.

\section{3 结论与展望}

本文介绍了LAMOST望远镜的结构、历史和主要 的科学目标. 目前LAMOST正在进行正式巡天, 主 要的巡天目标是银河系内恒星, 将在2017年6月中旬 完成 5 年的巡天任务. 预计在这 5 年的正式巡天中将 获取 700 多万天体的高信噪比光谱, 得到的恒星光谱 可以提供恒星的基本参数: 如有效温度、表面重力和 金属丰度, 以及视向速度的信息; 对晚型恒星我们还 可以得到它们 $\alpha$ 元素的丰度. 这些数据为科学家深人 研究银河系结构和演化, 精确描绘银河系, 银盘的星 族和星际介质的三维空间结构、恒星运动和金属丰度 分布, 揭示银河系恒星形成和化学增丰历史, 特别是 银盘的形成和化学演化历史提高可靠的观测资料. 目前, 科学家们正准备为LAMOST望远镜配备中等 分辨率的光谱仪, 中分辨率恒星光谱数据可以得到 更高精度的恒星视向速度, 特别是我们能获取高精 度的多种元素丰度的信息, 这些数据可以让科学家 们在元素丰度的水平上研究银盘形成和化学演化历 史, 并深人地了解银河系的运动学信息.

\section{参考文献}

1 Wang S G, Su D Q, Chu Y Q, et al. Special configuration of a very large Schmidt telescope for extensive astronomical sp ectroscopic observation. Appl Opt, 1996, 35: 5155-5161

2 Cui X Q, Zhao Y H, Chu Y Q, et al. The Large Sky Area Multi-Object Fiber Spectroscopic Telescope (LAMOST). Res Astron Astrophys, 2012, 12: 1197-1242

3 Zhao G, Zhao Y H, Chu Y Q, et al. LAMOST spectral survey-An overview. Res Astron Astrophys, 2012, 12: 723-734

4 Deng L C, Newberg H J, Liu C, et al. LAMOST Experiment for Galactic Understanding and Exploration (LEGUE)—The survey's science plan. Res Astron Astrophys, 2012, 12: 735-754 
5 Liu X W, Yuan H B, Huo Z Y, et al. LSS-GAC_A LAMOST spectroscopic survey of the galactic anti-center. IAU Symposium. Feltzing S, Zhao G, Walton N A, et al., eds. 2014, 298: 310-321

6 York D G, Adelman J, Anderson J E Jr, et al. The Sloan Digital Sky Survey: Technical summary. Astron J, 2000, 120: 1579-1587

7 Yanny B, Rockosi C, Newberg H J, et al. SEGUE: A spectroscopic survey of 240000 stars with $g=14-20$. Astron J, 2009, 137: 4377-4399

8 Nordström B, Mayor M, Andersen J, et al. The Geneva-Copenhagen survey of the Solarneighbourhood. Ages, metallicities, and kinematic properties of $\sim 14000 \mathrm{~F}$ and G dwarfs. Astron Astrophys, 2004, 418: 989-1019

9 Steinmetz M, Zwitter T, Siebert A, et al. The Radial Velocity Experiment (RAVE): First data release. Astron J, 2006, 132: 1645-1668

10 Allende Prieto C, Majewski S R, Schiavon R, et al. APOGEE: The Apache Point Observatory Galactic Evolution Experiment. Astron J, 2008, 136: 2070-2082

11 Freeman K C. The HERMES Project: Reconstructing Galaxy Formation. Galactic Archaeology: Near-Field Cosmology and the Formation of the Milky Way. In: Aoki W, Ishigaki M, Suda T, et al., eds. ASP Conference Proceedings, 2012, 458: 393

12 De Silva G M, Freeman K C, Bland-Hawthorn J, et al. The GALAH survey: Scientific motivation. Mon Not Roy Astron Soc, 2015, 449: 2604-2617

13 Perryman M A C, de Boer K S, Gilmore G, et al. GAIA: Composition, formation and evolution of the Galaxy. Astron Astrophys, 2001, 369: 339-363

14 de Jong R C, Barden S, Bellido-Tirado O, et al. 4MOST: 4-metre multi-object spectroscopic telescope. Proceedings of the SPIE, 2012, 8446, doi: $10.1117 / 12.926239$

15 Dalton G. Project overview and update on WEAVE: The next generation wide-field spectroscopy facility for the William Herschel Telescope. Proceedings of the SPIE, 2014, 9147, doi: 10.1117/12.2055132

16 Luo A L, Zhao Y H, Zhao G, et al. The first data release (DR1) of the LAMOST regular survey. Res Astron Astrophys, 2015, 15: $1095-1124$

17 Liu X W, Zhao G, Hou J L. Preface: The LAMOST Galactic surveys and early results. Res Astron Astrophys, 2015, 15: 1089 


\title{
The Large Sky Area Multi-Object Fiber Spectroscopic Telescope
}

\author{
SHI JianRong \\ National Astronomical Observatories, Chinese Academy of Sciences, Beijing 100012, China
}

The Large Sky Area Multi-Object Fiber Spectroscopic Telescope (LAMOST) adopts an innovative active optics technique that changes mirror surface continuously to achieve a series different reflecting Schmidt systems at different moments. The key technical innovations makes it a unique astronomical instrument combining the largest aperture with a wide field of view, and it is the telescope with the highest spectrum acquiring rate by 4000 fibers in the world. The observed declination of the telescope covers from $-10^{\circ}$ to $90^{\circ}$. There are two major components of the LAMOST survey: The LAMOST ExtraGAlactic Survey (LEGAS) and the LAMOST Experiment for Galactic Understanding and Exploration (LEGUE). It is known that the Milky Way is the only galaxy that we can study in enough detail, and the LEGUE survey can be divided into three parts according to sky coverage: the Galactic spheroid, the disk and the Galactic anticenter, and will observe a huge sample of stars of our Galaxy. At the moment, LAMOST survey focuses on the stellar spectra of our Galaxy, and will obtain optical spectra for statistically complete samples totaling at least 7.5 million Galactic stars from the thin- and thick-disk and halo during the first five year survey. It will open up new windows in near-field cosmology. LAMOST opened a new road to the large scale optical fiber spectroscopic sky surveys in China. As a national large scientific project, the spectra from the survey are opened to all Chinese astronomers. With this huge spectra database stellar kinematics can be obtained and the metallicity distribution function in the Galaxy will be derived, especially those within a few kpc of the Sun. With the structures revealed from such a large survey, it is possible for us to systematically map out the spatial density, Galactocentric rotation velocity and velocity ellipsoid, and chemical abundance of stars as a function of position in the Galaxy. These results will provide important constraints on the present models of Galactic structure, formation history, kinematical and dynamical evolution, chemical evolution, and the distribution of dark matter in the Milky Way. The survey will also provide important clues to the structure of the Galaxy's gravitational potential, and can pin down the mysterious of the possible structure and sub-structure of dark matter. Based on these results we can test models of dark matter, gravitational collapse, hydrodynamics of gas, stellar formation and feedback including properties of the first generation of stars and enrichment of interstellar medium through supernova explosions.

\section{LAMOST telescope, spectra survey, Galaxy formation and evolution}

doi: 10.1360/N972015-00975 